Biogeosciences Discuss., https://doi.org/10.5194/bg-2019-87

Manuscript under review for journal Biogeosciences

Discussion started: 29 April 2019

(c) Author(s) 2019. CC BY 4.0 License.

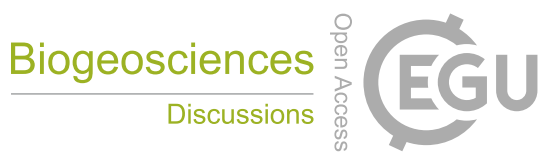

(c) (1)

\title{
1 Tree size and age induced stem carbon content variations cause an 2 uncertainty in forest carbon stock estimation
}

3 Suhui $\mathrm{Ma}^{1 *}$, Anwar Eziz ${ }^{1}$, Di Tian ${ }^{2}$, Zhengbing $\mathrm{Yan}^{1}$, Qiong $\mathrm{Cai}^{1}$, Mingwei Jiang ${ }^{1}$, Chengjun $\mathrm{Ji}^{1}$, Jingyun

$4 \quad$ Fang $^{1}$

$5 \quad{ }^{I}$ Department of Ecology, College of Urban and Environmental Sciences, Peking University, Beijing 100871, China

$6 \quad{ }^{2}$ College of Life Sciences, Capital Normal University, Beijing 100048, China

$7 \quad$ *Corresponding author: Suhui Ma

8 Email:mash2015@pku.edu.cn 
Biogeosciences Discuss., https://doi.org/10.5194/bg-2019-87

Manuscript under review for journal Biogeosciences

Discussion started: 29 April 2019

(c) Author(s) 2019. CC BY 4.0 License.

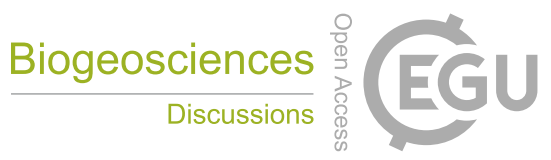

(c) (i)

9 Abstract. Stem carbon (C) content is widely used to present tree C content to estimate forest C stocks. However, size- and 10 age-dependent changes in tree stem $\mathrm{C}$ content are still unclear. Based on 576 tree size (expressed by diameter at breast height 11 (DBH) and biomass), age and $\mathrm{C}$ content data, our results showed that $\mathrm{C}$ content varied significantly among organs, and the 12 mean value of $\mathrm{C}$ content for bark, branch, leaf, reproductive organ, root and stem was $48.4 \%, 49.2 \%, 49.6 \%, 50.1 \%, 48.8 \%$, $1349.7 \%$, respectively. C content of stem was significantly correlated with that of leaf, branch and root, while showed no 14 relationship with that of bark and reproductive organ. With the increasing tree size and age, stem $\mathrm{C}$ content showed increasing 15 trends. Using stem $\mathrm{C}$ content as tree $\mathrm{C}$ content could produce an error of $-2.49 \%-5.87 \%$ in the estimations of forest $\mathrm{C}$ stock. 16 Thus, it is necessary to consider tree organ $\mathrm{C}$ content of stand in estimating forest $\mathrm{C}$ stock.

17 Keywords: stem carbon content, carbon stock estimation, forest, tree age, tree size. 
Biogeosciences Discuss., https://doi.org/10.5194/bg-2019-87

Manuscript under review for journal Biogeosciences

Discussion started: 29 April 2019

(c) Author(s) 2019. CC BY 4.0 License.

\section{Introduction}

Forest is an important component of terrestrial ecosystem, and can fix $1.1 \pm 0.8$ Pg carbon (C) per year from atmosphere through tree growth and biomass accumulation (Pan et al., 2011; Schlesinger and Bernhardt, 2013; Fang et al., 2018; Kirschbaum et al., 2019). Forest $\mathrm{C}$ stock is evaluated by multiplying total plant biomass by a corresponding plant $\mathrm{C}$ content (Ma et al., 2018; Martin et al., 2018). Thus, precise C content of tree is critical to estimate forest $\mathrm{C}$ stock and understand its role in global C cycle (Jones and O'Hara, 2016; Wu et al., 2017; Ma et al., 2018; Gillerot et al., 2018). As stem accounts for majority of tree biomass, generally, the canonical default value of $50 \%$ and specific stem wood $\mathrm{C}$ content have been used as tree C content in the estimations of forest C stocks at different scales (De Vries et al., 2006; IPCC, 2006; Lewis et al., 2009; Brienen et al., 2015; Braun et al., 2016; Carretero et al., 2017; Naveenkumar et al., 2017; Xu et al., 2017; Swetnam et al., 2017; Collins et al., 2019). Studies have indicated that using these methods could lead to possible error in forest $\mathrm{C}$ stock estimations due to differences in $\mathrm{C}$ content among organs as well as the variations of stem chemical components among tree sizes $(\mathrm{DBH})$ and ages (Martin and Thomas, 2013; Gillerot et al., 2018; Ma et al., 2018). Therefore, estimating the relationships of C content between tree organs and the variations of stem $\mathrm{C}$ content are important to improve the accuracy estimations of forest $\mathrm{C}$ stock.

Increasing evidences showed that C content of tree varied among organ types (Bert and Danjon, 2006; Yuan et al., 2011; Gillerot et al., 2018; Ma et al., 2018). For instance, stem C content in Pinus pinaster was higher than that in root, which might be related to the changes of chemical composition of tree organs (Bert and Danjon, 2006). In addition, a recent global synthesis of plant $\mathrm{C}$ content revealed significant variations of $\mathrm{C}$ content among woody plant organs (Ma et al., 2018). Thus, using stem $\mathrm{C}$ content as surrogate of that of a tree in forest $\mathrm{C}$ stock estimation, ignoring the $\mathrm{C}$ contents of other organs which share a high biomass proportion, will cause possible uncertainties (Zhang et al., 2009; Jones and O'Hara, 2018; Ma et al., 2018). Furthermore, Thomas and Martin (2012) have found significant differences in C content among tree organs, in which stem C content was significantly correlated with that of branch, bark and root with the exception of leaf. However, the relationship of $\mathrm{C}$ content among organs needs further verification. Most importantly, the relationship between $\mathrm{C}$ contents of stem and reproductive organs remains unclear.

In addition, stem C content of tree was tightly associated to tree size and age (Bert and Danjon, 2006; Noh et al., 2010; Peri et al., 2010; Uri et al., 2012; Martin and Thomas, 2013; Justine et al., 2017). This was likely related to tree growth process that, with increasing tree age and DBH, sapwood will convert to heartwood, resulting in an increase of heartwood proportion and stem wood C content of tree (Campbell et al., 1990; Pinto et al., 2004; Bert and Danjon, 2006; Lamlom and Savidge, 2006; Herrero de Aza et al., 2011; Jones and O’hara, 2011; Castaño-Santamaría and Bravo, 2012). For instance, Gao et al. (2016) found that the stem wood C content of three species in a boreal forest increased with the DBH. Similarly, Martin and Thomas (2013) found that stem C content of Miconia mirabilis in a tropical forest increased linearly with DBH. On the contrary, a study found that stem C content was higher in saplings than conspecific large trees (Martin et al., 2013). Moreover, regardless of close association between DBH and tree age, based on the limited survey data, several studies found that tree stem C content 
Biogeosciences Discuss., https://doi.org/10.5194/bg-2019-87

Manuscript under review for journal Biogeosciences

Discussion started: 29 April 2019

(c) Author(s) 2019. CC BY 4.0 License.

had no significant relationship with tree age (Ren et al., 2010; Cao et al., 2012; Ming et al., 2014; Cheng et al., 2015). Thus, it warrants systematic analysis on relationships among tree stem $\mathrm{C}$ content, tree size and age due to controversial results and little attention on the effect of tree size and age on stem C (Bert and Danjon, 2006).

Herein, we compiled a data set of $\mathrm{C}$ content of different tree organs from plantations or natural forest chronosequences. And we aimed to address the following two questions: (1) what are the relationships among C content of different tree organs? (2) how will tree stem $\mathrm{C}$ content vary with tree size and age and affect the estimations of forest $\mathrm{C}$ stock?

\section{Materials and methods}

\subsection{Data compilation}

To collect the literatures that provide species-specific tree organ C content data, we searched three databases (Web of Science, Google Scholar, China National Knowledge Infrastructure) using the search terms "carbon content", "carbon concentration", "carbon fraction", "organ", "tree", "age”, and "chronosequence" for papers published before May, 2017. At the same time, we collected papers from the references of literatures searched in the three databases. To guarantee the reliability and comparability of data, literatures were further selected satisfying certain criteria: (1) the data from the trees which grown in the control rather than in experimental treatment plot was included; (2) the data from at least three organs (must include stem) for each species was included; (3) the data from at least three age categories for each species was included. For each study, we recorded the location, taxonomic information (e.g. species name, genus and family), organ type (bark, branch, leaf, reproductive organ, root, and stem), tree age (measured tree age or stand age of plantation), DBH, biomass and C content. Specifically, stem wood was regarded as stem (exclude the bark component) in this study. Finally, our dataset contains 576 records, 24 species, 17 genera and 11 families from 30 literatures.

\subsection{Data analysis}

Firstly, possible effects of organ, age, site and species on tree C content were tested with Type III analysis of variances (ANOVA) (Table S1) (Ma et al., 2018). Similarly, for discrepancy of sample size among organs, differences of C content between organs were tested with Type III ANOVA in car packages (Thomas and Martin, 2012). Then using the Duncan.test, we conducted the multiple comparisons of means of organ $\mathrm{C}$ (Table 1). Pearson correlation analysis of $\mathrm{C}$ content of different organs was conducted (Table 2). The relationships between stem C content, tree size (DBH and biomass) and age were analysed by using a linear mixed-effects model with a random effect term of sites and species, which was useful for eliminating the possible effects of sites and species on the results (Zhang et al., 2012; Brienen et al., 2015). The weighted mean C content 
Biogeosciences Discuss., https://doi.org/10.5194/bg-2019-87

Manuscript under review for journal Biogeosciences

Discussion started: 29 April 2019

(c) Author(s) 2019. CC BY 4.0 License.

(c) (i)

Biomass proportion $_{i}=$ Biomass $_{i} / \sum_{i=1}^{n}$ Biomass $_{i}$

$W M C C=\sum_{i=1}^{6}$ Biomass proportion $_{i} \times C$ content $_{i}$

where Biomass $i$, Biomass proportion ${ }_{i}$, and $C$ content ${ }_{i}$ indicates the biomass, biomass proportion and C content of $i^{\text {th }}$ organ, respectively. $n$ is the number of organ.

The relative error of using a canonical value of $50 \%$ and stem $\mathrm{C}$ content as tree $\mathrm{C}$ content were calculated with the following Eq. (3) and Eq. (4) (Bert and Danjon, 2006):

Relative error of $50 \%=(50 \%-$ Stem C content $) /$ Stem C content $\times 100 \%$

Relative error of stem C content $=($ Stem C content - WMCC $) / W M C C \times 100 \%$

For each relative error, we calculated the statistical measures including sample size(N), arithmetic mean (Mean), standard deviation (SD), median, the 5\% percentile and 95\% percentile (Table 1). All statistical analyses of data were conducted with R 3.4.1. (R core Team 2017).

\section{Results}

\subsection{The variation of $\mathrm{C}$ content among tree organs}

The C content varied significantly among tree organs (Table S1), with a mean value of $48.4 \%, 49.2 \%, 49.6 \%, 50.1 \%, 48.8 \%$ and $49.7 \%$ for bark, branch, leaf, reproductive organs, root and stem, respectively. C contents in reproductive organ and stem were significantly higher than that in bark, branch and root (Table 1).

$\mathrm{C}$ content of stem, branch, leaf and root were significantly correlated with each other. C content of bark was significantly associated with that of branch, leaf, and root, while it was unrelated with that of stem and reproductive organ. Except for strong correlation with branch $\mathrm{C}$ content, reproductive organ $\mathrm{C}$ content has no significant relationship with $\mathrm{C}$ content in other parts of the tree (Table 2). Stem C content differed from that in other organs and could explain C content variations of $2.59 \%$, $60.10 \%, 36.90 \%, 11.90 \%$ and $34.60 \%$ in bark, branch, leaf, reproductive organs, root and stem, respectively (see Table S2).

\subsection{Size- and age-dependent changes in tree stem carbon content and their effects on estimating forest carbon stock}

Stem C content of tree increased significantly with increasing tree DBH $(p=0.005$, Figure 1a) and tree age $(p=0.01$, Figure $1 b$ ), with an average increase of $0.45 \%$ per $10 \mathrm{~cm}$ and $0.17 \%$ per 10 years (Figure 1), respectively. Additionally, stem C content increased with increasing biomass of both stem and tree (Figure 2). As the biomass of tree and the corresponding proportion 
Biogeosciences Discuss., https://doi.org/10.5194/bg-2019-87

Manuscript under review for journal Biogeosciences

Discussion started: 29 April 2019

(c) Author(s) 2019. CC BY 4.0 License.

varied among organ and tree ages (Figure 3), compared with the WMCC, using both the canonical value of 50\% and stem C content could lead to errors for estimating tree C content (-8.62\%-13.71\% and $-2.49-5.87 \%$, respectively, see Table S3), in which error resulted from stem C content decreased with increasing tree age (Figure 4).

\section{Discussion}

Tree organ $\mathrm{C}$ content plays a critical role in forest $\mathrm{C}$ stock estimations at large scales but poorly estimated. Our dataset showed that tree $\mathrm{C}$ content ranged from $48.4 \%$ to $50.1 \%$, which was consistent with results of previous studies (Alriksson and Eriksson, 1998; Bert and Danjon, 2006; Martin et al., 2015; Yao et al., 2015) but higher than that of woody plants (47.4\%-48.6\%) in the global plant organ $\mathrm{C}$ content database (Ma et al., 2018). This indicated that $\mathrm{C}$ content in tree is higher than that in shrub due to a lower lignification of shrub. Consistent with that of global woody plants (Ma et al., 2018), tree C content in our study varied significantly among organs and was higher in reproductive organ but lower in root. Differences in specific function and chemical compositions between organs may predominate the variation of C content among organs (Bert and Danjon, 2006; Thomas and Martin, 2012). For instance, organs with a high $\mathrm{C}$ content are associated with a high lignin because it is one of the most common polymers and is rich in C (with C content of $~ 66 \%$ ) (Pettersen, 1984; Ma et al., 2018). It is generally believed that lignin in root is less than that in stem and reproductive organs owing to mechanical support and disease resistance (Vance et al., 1980). Variation of tree $\mathrm{C}$ content among organs indicated that excepted for stem, $\mathrm{C}$ content in other organs should be paid attention in the field of plant stoichiometry and forest $\mathrm{C}$ stock estimations.

Additionally, our results showed that the tree $\mathrm{C}$ content in stem, root, leaf and branch were significantly correlated with each other. Thomas and Martin (2012) also found a relationship of tree C content in stem, branch and root. This suggests that the key chemical traits determining the $\mathrm{C}$ content of tree organs may depend on genetic constraints (Thomas and Martin, 2012). However, our results also showed that $\mathrm{C}$ content of reproductive organ had no relationship with that of other organs (except branch), which is presumably determined by the specific functions of reproductive organs (Ma et al., 2018). Generally, reproductive organs in plants contain high levels of lignin for defence and protein for reproductions (Bazzaz et al., 1987; Rouwenhorst et al., 1991), which is rich in C (Bert and Danjon, 2006). There was no relationship between C content of stem and bark due to differences in phenolic, extract, lignin and cellulose content of the two organs (Bert and Danjon, 2006). The differences in chemical compositions of stem and other organs may lead to that stem $\mathrm{C}$ content differed from that in other organs. Specifically, stem C content had relationships with that of branch, leaf and root, and could partially explain the variations in $\mathrm{C}$ content of other organs $(2.59 \%-60.10 \%$, Table S2), indicating complicated relationships between $\mathrm{C}$ content of stem and other organs.

Although stem C content is one of key tree chemical traits, it has received much less attention (Martin et al., 2018). Our results indicated that tree stem C content increased significantly with increasing DBH, which was also reported by Martin and 
Biogeosciences Discuss., https://doi.org/10.5194/bg-2019-87

Manuscript under review for journal Biogeosciences

Discussion started: 29 April 2019

(c) Author(s) 2019. CC BY 4.0 License.

content may be associated with the changes in volatile $\mathrm{C}$ content and $\mathrm{C}$-rich structural compounds including like lignin and cellulose of trees (Bert and Danjon, 2006; Martin et al., 2013; Martin and Thomas, 2013; Gao et al., 2016). A recent study indicated that volatile $C$ content in stem is the key drivers of stem $C$ content variation (Gao et al., 2016). However, it contradicted with our results due to the reason that $\mathrm{C}$ content in our data set was measured by oven-dried method, which could cause volatile $\mathrm{C}$ loss (Gao et al., 2016). Thus, this suggests that size-dependent changes of stem $\mathrm{C}$ content in our study may primarily attributed to the shifts of chemical composition in stem (Bert and Danjon, 2006; Herrero de Aza et al., 2011). With increasing tree DBH, sapwood will convert to heartwood then lead to an increase of C-rich structural components. This process mainly includes the loss of the stored starch of ray parenchyma cells, death and lignification of parenchyma cells and deposition of extractives (Bamber, 1976; Pinto et al., 2004; Knapic and Pereira, 2005; Bert and Danjon, 2006). The accumulation of Crich structural compounds may cause an increase of stem $\mathrm{C}$ contents in the process of tree growth. For instance, according to the relationship of heartwood and DBH of Pinus pinaster and C content in heartwood and sapwood (Pinto et al., 2004; Herrero de Aza et al., 2011), stem C content will increase from 45.9\% to 46.5\% when DBH increase from $10 \mathrm{~cm}$ to $60 \mathrm{~cm}$. The increase of stem C content resulted from DBH may lead to stem C content increased with increasing tree age and biomass. Several studies have also found that stem C content varied significantly as a function of tree age (Peri et al., 2010; Uri et al., 2012; Zhang et al., 2014; Justine et al., 2017).

The uncertainty in forest $\mathrm{C}$ stock estimations derived from the canonical value of 50\% or stem $\mathrm{C}$ content at large scales remain unclear due to lack of corresponding biomass data in previous three global $\mathrm{C}$ content databases (Martin and Thomas, 2011; Martin et al., 2018; Ma et al., 2018). As mentioned above, using the canonical value of 50\% as tree $\mathrm{C}$ content may neglecting age-dependent changes of stem $\mathrm{C}$ content as well as variation of $\mathrm{C}$ content among tree organs, resulting in an error of $-8.62 \%-13.71 \%$ in forest $\mathrm{C}$ stock estimations (Table S3), which was comparable with previous studies in finding that canonical value could induce errors between $3.77-13.8 \%$ in regional C stock estimations (Bert and Danjon, 2006; Tolunay, 2009; Fang et al., 2010; Rodrigues et al., 2015). Most importantly, using stem C content as tree C content (WMCC) could introduce an error of $-2.49 \%-5.87 \%$ in forest $\mathrm{C}$ stock (Table S3). These errors of global forest $\mathrm{C}$ stocks (Pan et al., 2011) could create -9.0-21.3 Pg C variation, which is greater than the vegetation C pools of Europe (9 Pg C) (Dixon et al., 1994). Moreover, the errors of using stem C content as the WMCC decreased significantly with tree age but showed no significant relationship with DBH. This may be related to the variation of organ $\mathrm{C}$ content and biomass proportion with tree age. Stem biomass of trees increased with increasing tree size and age (Figure 3) (Poorter et al. 2012). Therefore, the stem $\mathrm{C}$ content has significant contribution to the WMCC with increasing tree age, indicating that the risk of over estimation or under estimation will be great estimating forest $\mathrm{C}$ stock. 
Biogeosciences Discuss., https://doi.org/10.5194/bg-2019-87

Manuscript under review for journal Biogeosciences

Discussion started: 29 April 2019

(c) Author(s) 2019. CC BY 4.0 License.

\section{Conclusions}

166

167

168

169

170

Tree $\mathrm{C}$ content in our dataset varied with organs and ranged from $48.4 \%$ to $50.1 \%$, which could be used as the species- or agespecific $\mathrm{C}$ fractions in forest $\mathrm{C}$ stock estimations at regional or large scales. There were complicated relationships between $\mathrm{C}$ content in stem and that in other organs. Stem C content could partially represent C content of other organs $(2.59 \%-60.10 \%)$. Moreover, stem $\mathrm{C}$ content increased significantly with increasing DBH, age and biomass, suggesting stem C content in tree as one of the important plant traits that should be taken into consideration in the research of plant ecological stoichiometry and plant functional biology. Most importantly, ignoring the relationships of $\mathrm{C}$ content in different organs as well as size-and agedependent changes of tree stem $\mathrm{C}$ content, using the canonical value of $50 \%$ and mean stem $\mathrm{C}$ content could lead to estimation errors of forest $\mathrm{C}$ stock (-8.62\%-13.71\% and $2.49 \%-5.87 \%$, respectively). In future, the estimations of forest $\mathrm{C}$ stock should pay more attention to the error from size- and age-dependent changes in stem $\mathrm{C}$ content and consider $\mathrm{C}$ content of different tree organs of stand.

\section{Acknowledgements}

This work was supported by the National Key Research and Development Program of China (2017YFC0503903) and the Natural Science Foundation of China (31621091). We thank Jianxiao Zhu, Lai Jiang, Haojie Su, Guoping Chen, Ming Ouyang, Yuhao Feng, and Zhiyao Tang for their helpful suggestions for data analysis and a friendly review of the manuscript.

\section{References}

Alriksson, A., and Eriksson, H. M.: Variations in mineral nutrient and C distribution in the soil and vegetation compartments of five temperate tree species in NE Sweden, Forest Ecol. Manag., 108, 261-273, 1998.

Bamber, R. K.: Heartwood, Its function and formation, Wood Sci. Technol., 10, 1-8, 1976.

Bazzaz, F. A., Chiariello, N. R., Coley, P. D., and Pitelka, L. F.: Allocating resources to reproduction and defense, Bioscience, 37, 58-67, 1987.

Bert, D., and Danjon, F.: Carbon concentration variations in the roots, stem and crown of mature Pinus pinaster (Ait.), Forest Ecol. Manag., 222, 279-295, 2006.

Braun, M., Fritz, D., Weiss, P., Braschel, N., Büchsenmeister, R., Freudenschuß, A., Gschwantner, T., Jandl, R., Ledermann, T., Neumann, M., Pölz, W., Schadauer, K., Schmid, C., Schwarzbauer, P., and Stern, T.: A holistic assessment of greenhouse gas dynamics from forests to the effects of wood products use in Austria, Carbon Manag., 7, 271-283, 2016.

Brienen, R. J. W., Phillips, O. L., Feldpausch, T. R., Gloor, E., Baker, T. R., Lloyd, J., Lopez-Gonzalez, G., MonteagudoMendoza, A., Malhi, Y., Lewis, S. L., Vásquez Martinez, R., Alexiades, M., Álvarez Dávila, E., Alvarez-Loayza, P., Andrade, A., Aragão, L. E. O. C., Araujo-Murakami, A., Arets, E. J. M. M., Arroyo, L., Aymard C, G. A., Bánki, O. 
Biogeosciences Discuss., https://doi.org/10.5194/bg-2019-87

Manuscript under review for journal Biogeosciences

Discussion started: 29 April 2019

(c) Author(s) 2019. CC BY 4.0 License.

(c) (i)

S., Baraloto, C., Barroso, J., Bonal, D., Boot, R. G. A., Camargo, J. L. C., Castilho, C. V., Chama, V., Chao, K. J., Chave, J., Comiskey, J. A., Cornejo Valverde, F., da Costa, L., de Oliveira, E. A., Di Fiore, A., Erwin, T. L., Fauset, S., Forsthofer, M., Galbraith, D. R., Grahame, E. S., Groot, N., Hérault, B., Higuchi, N., Honorio Coronado, E. N., Keeling, H., Killeen, T. J., Laurance, W. F., Laurance, S., Licona, J., Magnussen, W. E., Marimon, B. S., MarimonJunior, B. H., Mendoza, C., Neill, D. A., Nogueira, E. M., Núñez, P., Pallqui Camacho, N. C., Parada, A., PardoMolina, G., Peacock, J., Peña-Claros, M., Pickavance, G. C., Pitman, N. C. A., Poorter, L., Prieto, A., Quesada, C. A., Ramírez, F., Ramírez-Angulo, H., Restrepo, Z., Roopsind, A., Rudas, A., Salomão, R. P., Schwarz, M., Silva, N., Silva-Espejo, J. E., Silveira, M., Stropp, J., Talbot, J., ter Steege, H., Teran-Aguilar, J., Terborgh, J., Thomas-Caesar, R., Toledo, M., Torello-Raventos, M., Umetsu, R. K., van der Heijden, G. M. F., van der Hout, P., Guimarães Vieira, I. C., Vieira, S. A., Vilanova, E., Vos, V. A., and Zagt, R. J.: Long-term decline of the Amazon carbon sink, Nature, $519,344,2015$.

Campbell, A. G., Kim, W. J., and Koch, P.: Chemical variation in lodgepole pine with sapwood/heartwood, stem height, and variety, Wood Fiber Sci., 22, 22-30, 1990.

Cao, J., Wang, X., Tian, Y., Wen, Z., and Zha, T.: Pattern of carbon allocation across three different stages of stand development of a Chinese pine (Pinus tabulaeformis) forest, Ecol. Res., 27, 883-892, 2012.

Carretero, E. M., Moreno, G., Duplancic, A., Abud, A., Vento, B., and Jauregui, J. A.: Urban forest of Mendoza (Argentina): the role of Morus alba (Moraceae) in carbon storage, Carbon Management, 8, 237-244, 2017.

Castaño-Santamaría, J., and Bravo, F.: Variation in carbon concentration and basic density along stems of sessile oak (Quercus petraea (Matt.) Liebl.) and Pyrenean oak (Quercus pyrenaica Willd.) in the Cantabrian Range (NW Spain), Ann. Forest Sci., 69, 663-672, 2012.

Cheng, J., Lee, X., Theng, B. K. G., Zhang, L., Fang, B., and Li, F.: Biomass accumulation and carbon sequestration in an agesequence of Zanthoxylum bungeanum plantations under the Grain for Green Program in karst regions, Guizhou province, Agr. Forest Meteorol., 203, 88-95, 2015.

Collins, L., Bradstock, R., Ximenes, F., Horsey, B., Sawyer, R., and Penman, T.: Above-ground forest carbon shows different responses to fire frequency in harvested and unharvested forests, Ecol. Appl., 29, e01815, 2019.

De Vries, W., Reinds, G. J., Gundersen, P., and Sterba, H.: The impact of nitrogen deposition on carbon sequestration in European forests and forest soils, Glob. Change Biol., 12, 1151-1173, 2006.

Dixon, R. K., Solomon, A. M., Brown, S., Houghton, R. A., Trexier, M. C., and Wisniewski, J.: Carbon pools and flux of global forest ecosystems, Science, 263, 185-190, 1994.

Fang, J., Yu, G., Liu, L., Hu, S., and Chapin, F. S., III: Climate change, human impacts, and carbon sequestration in China, P. Natl. Acad. Sci. USA, 115, 4015-4020, 2018.

Fang, S., Li, H., Sun, Q., and Chen, L.: Biomass production and carbon stocks in poplar-crop intercropping systems: a case study in northwestern Jiangsu, China, Agroforest Syst., 79, 213-222, 2010. 
Biogeosciences Discuss., https://doi.org/10.5194/bg-2019-87

Manuscript under review for journal Biogeosciences

Discussion started: 29 April 2019

(c) Author(s) 2019. CC BY 4.0 License.

Gao, B., Taylor, A. R., Chen, H. Y. H., and Wang, J.: Variation in total and volatile carbon concentration among the major tree species of the boreal forest, Forest Ecol. Manag., 375, 191-199, 2016.

Gillerot, L., Vlaminck, E., De Ryck, D. J. R., Mwasaru, D. M., Beeckman, H., and Koedam, N.: Inter- and intraspecific variation in mangrove carbon fraction and wood specific gravity in Gazi Bay, Kenya, Ecosphere, 9, e02306, https://doi.org/10.1002/ecs2.2306, 2018.

Herrero de Aza, C., Belen Turrion, M., Pando, V., and Bravo, F.: Carbon in heartwood, sapwood and bark along the stem profile in three Mediterranean Pinus species, Ann. Forest Sci., 68, 1067-1076, https://doi.org/10.1007/s13595-0110122-y, 2011.

IPCC: Forest lands, Intergovernmental Panel on Climate Change Guidelines for National Greenhouse Gas Inventories, Institute for Global Environmental Strategies (IGES), Hayama, Japan, 2006.

Jones, D. A., and O'hara, K. L.: Carbon density in managed coast redwood stands: implications for forest carbon estimation, Forestry, 85, 99-110, 2011.

Jones, D. A., and O'Hara, K. L.: The influence of preparation method on measured carbon fractions in tree tissues, Tree Physiol., 36, 1177-1189, https://doi.org/10.1093/treephys/tpw051, 2016.

Jones, D. A., and O'Hara, K. L.: Variation in carbon fraction, density, and carbon density in conifer tree tissues, Forests, 9, 19, https://doi.org/10.3390/f9070430, 2018.

Justine, M. F., Yang, W., Wu, F., and Khan, M. N.: Dynamics of biomass and carbon sequestration across a chronosequence of masson pine plantations, J. Geoph. Res.: Biogeosciences, 122, 578-591, https://doi.org/10.1002/2016jg003619, 2017.

Kirschbaum, M. U. F., Zeng, G., Ximenes, F., Giltrap, D. L., and Zeldis, J. R.: Towards a more complete quantification of the global carbon cycle, Biogeosciences, 16, 831-846, https://doi.org/10.5194/bg-16-831-2019, 2019.

Knapic, S., and Pereira, H.: Within-tree variation of heartwood and ring width in maritime pine (Pinus pinaster Ait.), Forest Ecol. Manag., 210, 81-89, https://doi.org/10.1016/j.foreco.2005.02.017, 2005.

Lamlom, S. H., and Savidge, R. A.: Carbon content variation in boles of mature sugar maple and giant sequoia, Tree Physiol., 26, 459-468, 2006.

Lewis, S. L., Lopez-Gonzalez, G., Sonke, B., Affum-Baffoe, K., Baker, T. R., Ojo, L. O., Phillips, O. L., Reitsma, J. M., White, L., Comiskey, J. A., Djuikouo, M. N., Ewango, C. E. N., Feldpausch, T. R., Hamilton, A. C., Gloor, M., Hart, T., Hladik, A., Lloyd, J., Lovett, J. C., Makana, J. R., Malhi, Y., Mbago, F. M., Ndangalasi, H. J., Peacock, J., Peh, K. S. H., Sheil, D., Sunderland, T., Swaine, M. D., Taplin, J., Taylor, D., Thomas, S. C., Votere, R., and Woll, H.: Increasing carbon storage in intact African tropical forests, Nature, 457, https://doi.org/10.1038/nature07771, 2009.

Ma, S., He, F., Tian, D., Zou, D., Yan, Z., Yang, Y., Zhou, T., Huang, K., Shen, H., and Fang, J.: Variations and determinants of carbon content in plants: a global synthesis, Biogeosciences, 15, 693-702, https://doi.org/10.5194/bg-15-693-2018, 2018. 
Biogeosciences Discuss., https://doi.org/10.5194/bg-2019-87

Manuscript under review for journal Biogeosciences

Discussion started: 29 April 2019

(c) Author(s) 2019. CC BY 4.0 License.

Martin, A. R., and Thomas, S. C.: Size-dependent changes in leaf and wood chemical traits in two Caribbean rainforest trees, Tree Physiol., 33, 1338-1353, https://doi.org/10.1093/treephys/tpt085, 2013.

Martin, A. R., Thomas, S. C., and Zhao, Y.: Size-dependent changes in wood chemical traits: a comparison of neotropical saplings and large trees, AoB Plants, 5, plt039, 2013.

Martin, A. R., Gezahegn, S., and Thomas, S. C.: Variation in carbon and nitrogen concentration among major woody tissue types in temperate trees, Can J Forest Res, 45, 744-757, 2015.

Martin, A. R., Doraisami, M., and Thomas, S. C.: Global patterns in wood carbon concentration across the world's trees and forests, Nat. Geosc., 11, 915-920, https://doi.org/10.1038/s41561-018-0246-x, 2018.

Ming, A., Jia, H., Zhao, J., Tao, Y., and Li, Y.: Above- and below-ground carbon stocks in an indigenous tree (Mytilaria laosensis) plantation chronosequence in subtropical China, Plos One, 9, e109730, 2014.

Naveenkumar, J., Arunkumar, K. S., and Sundarapandian, S. M.: Biomass and carbon stocks of a tropical dry forest of the Javadi Hills, Eastern Ghats, India, Carbon Manag., 8, 351-361, https://doi.org/10.1080/17583004.2017.1362946, 2017.

Noh, N. J., Son, Y., Lee, S. K., Seo, K. W., Heo, S. J., Yi, M. J., Park, P. S., Kim, R. H., Son, Y. M., and Lee, K. H.: Carbon and nitrogen storage in an age-sequence of Pinus densiflora stands in Korea, Sci. China Life Sci., 53, 822-830, https://doi.org/10.1007/s11427-010-4018-0, 2010.

Pan, Y. D., Birdsey, R. A., Fang, J. Y., Houghton, R., Kauppi, P. E., Kurz, W. A., Phillips, O. L., Shvidenko, A., Lewis, S. L., Canadell, J. G., Ciais, P., Jackson, R. B., Pacala, S. W., McGuire, A. D., Piao, S. L., Rautiainen, A., Sitch, S., and Hayes, D.: A large and persistent carbon sink in the world's forests, Science, 333, 988-993, https://doi.org/10.1126/science.1201609, 2011.

Peri, P. L., Gargaglione, V., Pastur, G. M., and Lencinas, M. V.: Carbon accumulation along a stand development sequence of Nothofagus antarctica forests across a gradient in site quality in Southern Patagonia, Forest Ecol. Manag., 260, 229237, 2010.

Pettersen, R. C.: The chemical composition of wood, in: The Chemistry of Wood. Advances in Chemistry Series 207, edited by: Rowel, R. M., ACS Publications, Washington, DC, 57-126, 1984.

Pinto, I., Pereira, H., and Usenius, A.: Heartwood and sapwood development within maritime pine (Pinus pinaster Ait.) stems, Trees Struct. Funct., 18, 284-294, https://doi.org/10.1007/s00468-003-0305-8, 2004.

Poorter, H., Niklas, K. J., Reich, P. B., Oleksyn, J., Poot, P., and Mommer, L.: Biomass allocation to leaves, stems and roots: meta-analyses of interspecific variation and environmental control, New Phytol., 193, 30-50, 2012.

Ren, H., Chen, H., Li, Z. a., and Han, W.: Biomass accumulation and carbon storage of four different aged Sonneratia apetala plantations in Southern China, Plant Soil, 327, 279-291, 2010.

Rodrigues, D. P., Hamacher, C., Estrada, G. C. D., and Soares, M. L. G.: Variability of carbon content in mangrove species: Effect of species, compartments and tidal frequency, Aquat. Bot., 120, 346-351, 2015. 
Biogeosciences Discuss., https://doi.org/10.5194/bg-2019-87

Manuscript under review for journal Biogeosciences

Discussion started: 29 April 2019

(c) Author(s) 2019. CC BY 4.0 License.

Rouwenhorst, R. J., Jzn, J. F., Scheffers, W. A., and van Dijken, J. P.: Determination of protein concentration by total organic carbon analysis, J. Biochem. Bioph. Meth., 22, 119-128, 1991.

Schlesinger, W. H., and Bernhardt, E. S.: Chapter 5 - The biosphere: The carbon cycle of terrestrial ecosystems, Elsevier Inc., 2013.

Swetnam, T. L., Brooks, P. D., Barnard, H. R., Harpold, A. A., and Gallo, E. L.: Topographically driven differences in energy and water constrain climatic control on forest carbon sequestration, Ecosphere, 8, e01797, doi:10.1002/ecs2.1797, 2017.

R Core Team: A language and environment for statistical computing. R foundation for statistical computing, Vienna, Austria,https://www.R-project.org/, 2017.

Thomas, S. C., and Martin, A. R.: Carbon content of tree tissues: a synthesis, Forests, 3, 332-352, https://doi.org/10.3390/f3020332, 2012.

Tolunay, D.: Carbon concentrations of tree components, forest floor and understorey in young Pinus sylvestris stands in northwestern Turkey, Scand. J. Forest Res., 24, 394-402, 2009.

Uri, V., Varik, M., Aosaar, J., Kanal, A., Kukumägi, M., and Lõhmus, K.: Biomass production and carbon sequestration in a fertile silver birch (Betula pendula Roth) forest chronosequence, Forest Ecol. Manag., 267, 117-126, 2012.

Vance, C. P., Kirk, T. K., and Sherwood, R. T.: Lignification as a mechanism of disease resistance, Ann. Rev. Phytopathol., 18, 259-288, 1980.

Wu, H., Xiang, W., Fang, X., Lei, P., Ouyang, S., and Deng, X.: Tree functional types simplify forest carbon stock estimates induced by carbon concentration variations among species in a subtropical area, Sci. Rep., 7, 4992, 2017.

Xu, B., Pan, Y., Plante, A. F., McCullough, K., and Birdsey, R.: Modeling forest carbon cycle using long-term carbon stock field measurement in the Delaware River Basin, Ecosphere, 8, e01802, https://doi.org/10.1002/ecs2.1802, 2017.

Yao, F., Chen, Y., Yan, Z., Li, P., Han, W., and Fang, J.: Biogeographic patterns of structural traits and C:N:P stoichiometry of tree twigs in China's forests, Plos One, 10, e0116391, https://doi.org/10.1371/journal.pone.0116391, 2015.

Yuan, Z., Chen, H. Y., and Reich, P. B.: Global-scale latitudinal patterns of plant fine-root nitrogen and phosphorus, Nat. Commun., 2, 344, 2011.

Zhang, H., Song, T., Wang, K., Du, H., Yue, Y., Wang, G., and Zeng, F.: Biomass and carbon storage in an age-sequence of Cyclobalanopsis glauca plantations in southwest China, Ecol. Eng., 73, 184-191, 2014.

Zhang, Q., Wang, C., Wang, X., and Quan, X.: Carbon concentration variability of 10 Chinese temperate tree species, Forest Ecol Manag, 258, 722-727, 2009.

Zhang, S. B., Zhang, J. L., Slik, J. W. F., and Cao, K. F.: Leaf element concentrations of terrestrial plants across China are influenced by taxonomy and the environment, Global Ecol. Biogeogr., 21, 809-818, 2012. 
Biogeosciences Discuss., https://doi.org/10.5194/bg-2019-87

Manuscript under review for journal Biogeosciences

Discussion started: 29 April 2019

(c) Author(s) 2019. CC BY 4.0 License.

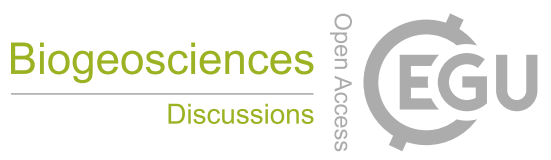

\section{Tables}

326 Table 1. Carbon content of tree varied significantly among organs. $n$ indicates the sample size. SD, Min and Max are the 327 abbreviation of standard deviation, minimum and maximum, respectively. The mean values of carbon content of organs with 328 the same letter are not significantly different.

\begin{tabular}{lccccc}
\hline Organs & $n$ & Mean & SD & Min & Max \\
\hline Bark & 65 & $48.37 \mathrm{e}$ & 3.91 & 39.52 & 56.72 \\
Branch & 132 & $49.18 \mathrm{~cd}$ & 3.55 & 39.45 & 56.23 \\
Leaf & 128 & $49.59 \mathrm{bc}$ & 4.09 & 36.70 & 58.61 \\
Reproductive organ & 20 & $50.09 \mathrm{a}$ & 2.94 & 45.78 & 54.42 \\
Root & 99 & $48.83 \mathrm{de}$ & 3.22 & 40.87 & 55.00 \\
Stem & 132 & $49.74 \mathrm{ab}$ & 3.04 & 44.26 & 57.24 \\
\hline
\end{tabular}


Biogeosciences Discuss., https://doi.org/10.5194/bg-2019-87

Manuscript under review for journal Biogeosciences

Discussion started: 29 April 2019

(c) Author(s) 2019. CC BY 4.0 License.

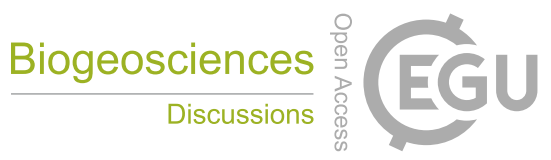

330 Table 2. Pearson correlation coefficients of relationship between carbon content of organs. Values in coefficients indicated by 331 asterisk are significant $(p<0.05)$.

\begin{tabular}{|c|c|c|c|c|c|c|}
\hline & & & & Reproductive & & \\
\hline & Bark & Branch & Leaf & organ & Root & Stem \\
\hline Bark & 1 & & & & & \\
\hline Branch & $0.45^{* * *}$ & 1 & & & & \\
\hline Leaf & $0.58^{* * *}$ & $0.70^{* * *}$ & 1 & & & \\
\hline Reproductive organ & -0.30 & $0.58^{* *}$ & 0.18 & 1 & & \\
\hline Root & $0.55^{* * *}$ & $0.67 * * *$ & $0.55^{* * *} *$ & 0.05 & 1 & \\
\hline Stem & 0.16 & $0.78 * * *$ & $0.61 * * *$ & 0.35 & $0.59 * * *$ & 1 \\
\hline
\end{tabular}

$* p<0.05 ; * * p<0.01 ; * * * p<0.001$. 
Biogeosciences Discuss., https://doi.org/10.5194/bg-2019-87

Manuscript under review for journal Biogeosciences

Discussion started: 29 April 2019

(c) Author(s) 2019. CC BY 4.0 License.

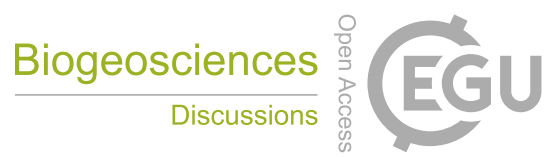

(c) $\underset{\mathrm{BY}}{\mathrm{B}}$

Figures

334 Figure 1. Stem carbon content of tree increase significantly with DBH (a) and tree age (b). k indicates slope of DBH and tree 335 age in a mixed linear model. Abbreviations: DBH refers to the diameter at breast height.
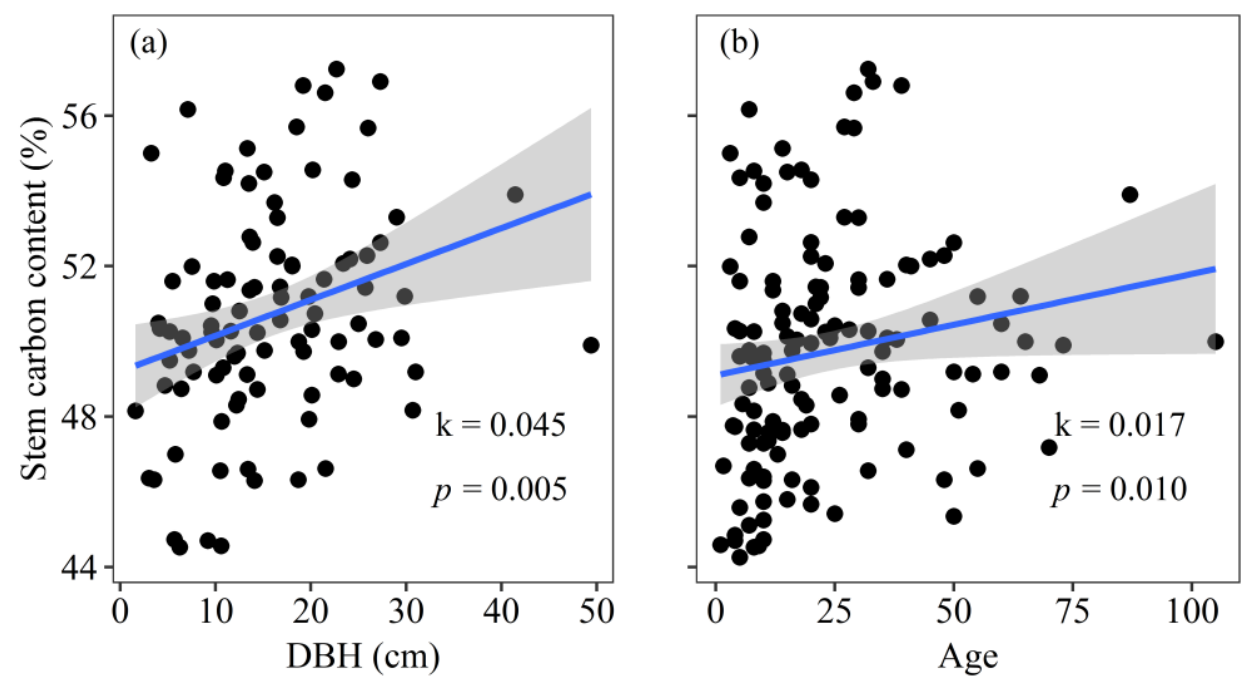
Biogeosciences Discuss., https://doi.org/10.5194/bg-2019-87

Manuscript under review for journal Biogeosciences

Discussion started: 29 April 2019

(c) Author(s) 2019. CC BY 4.0 License.

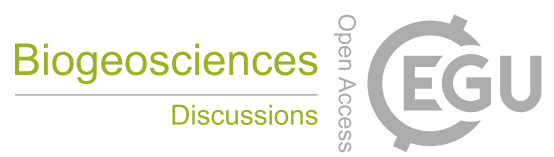

(c) $\underset{\mathrm{Br}}{\mathrm{Br}}$

337 Figure 2. Stem carbon content of tree increase significantly with increasing stem biomass (a) and tree biomass (b). k indicates 338 slope of biomass of stem and tree in a mixed linear model.
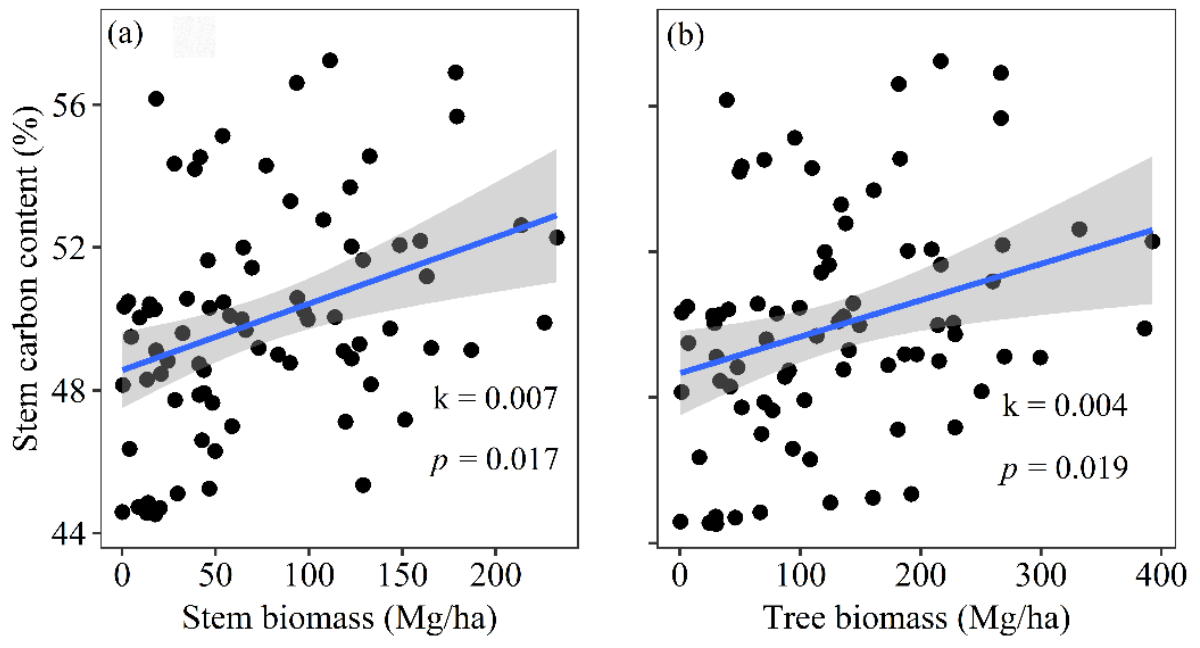
Biogeosciences Discuss., https://doi.org/10.5194/bg-2019-87

Manuscript under review for journal Biogeosciences

Discussion started: 29 April 2019

(c) Author(s) 2019. CC BY 4.0 License.

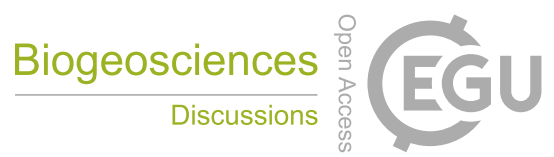

(c) (i)

340 Figure 3. Organ biomass (a) and its proportion (b) of tree varied with tree age.
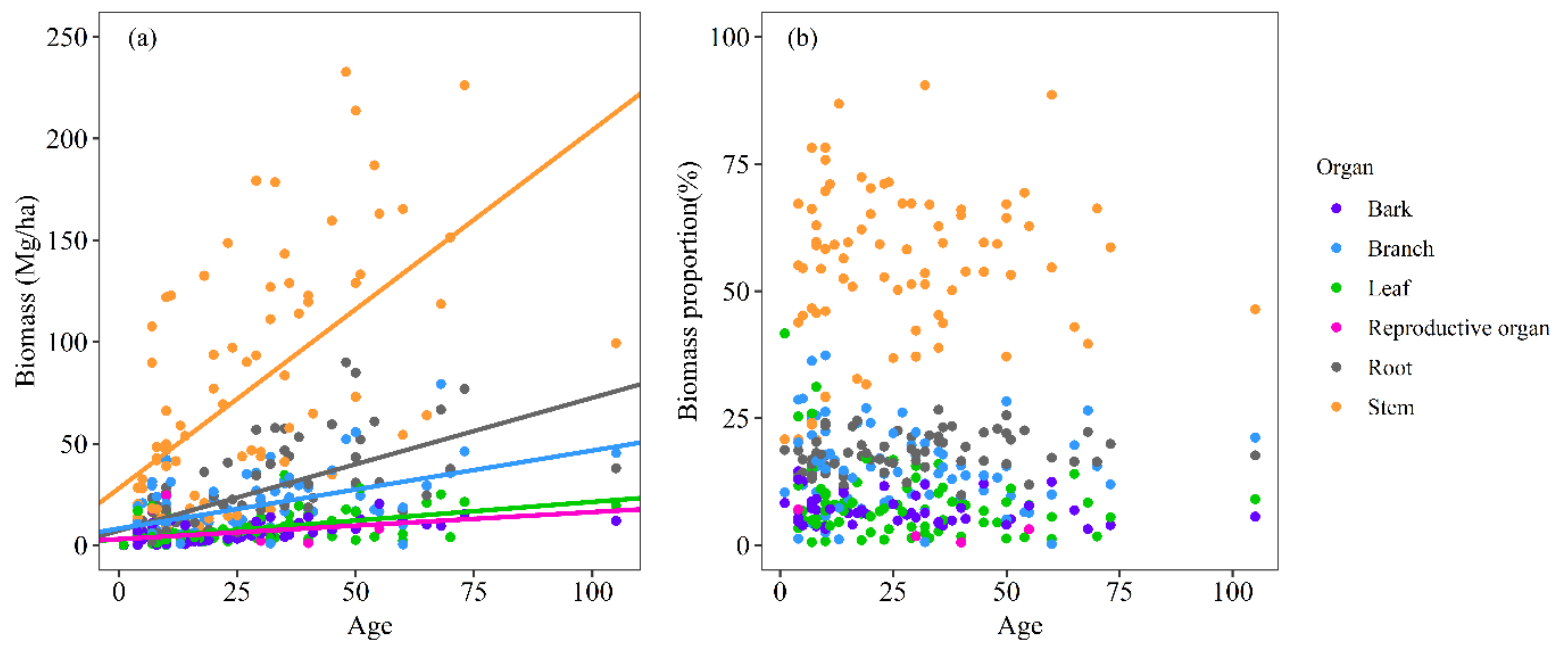
Biogeosciences Discuss., https://doi.org/10.5194/bg-2019-87

Manuscript under review for journal Biogeosciences

Discussion started: 29 April 2019

(c) Author(s) 2019. CC BY 4.0 License.

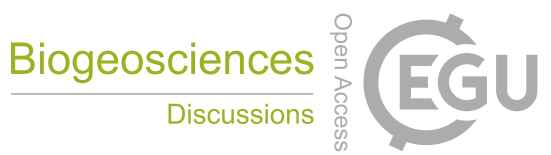

(c) (i)

342 Figure 4. Relative error of using stem carbon content as the WMCC varied with tree DBH (a) and age (b) in forest C stock 343 estimations. Solid line indicates the significant relationships with $p<0.05$, and dashed line denotes the insignificant 344 relationships with $p>0.05$. $\mathrm{k}$ indicates slope of DBH and tree age. Abbreviations: The WMCC refers to the weighted mean 345 carbon content; DBH refers to the diameter at breast height.
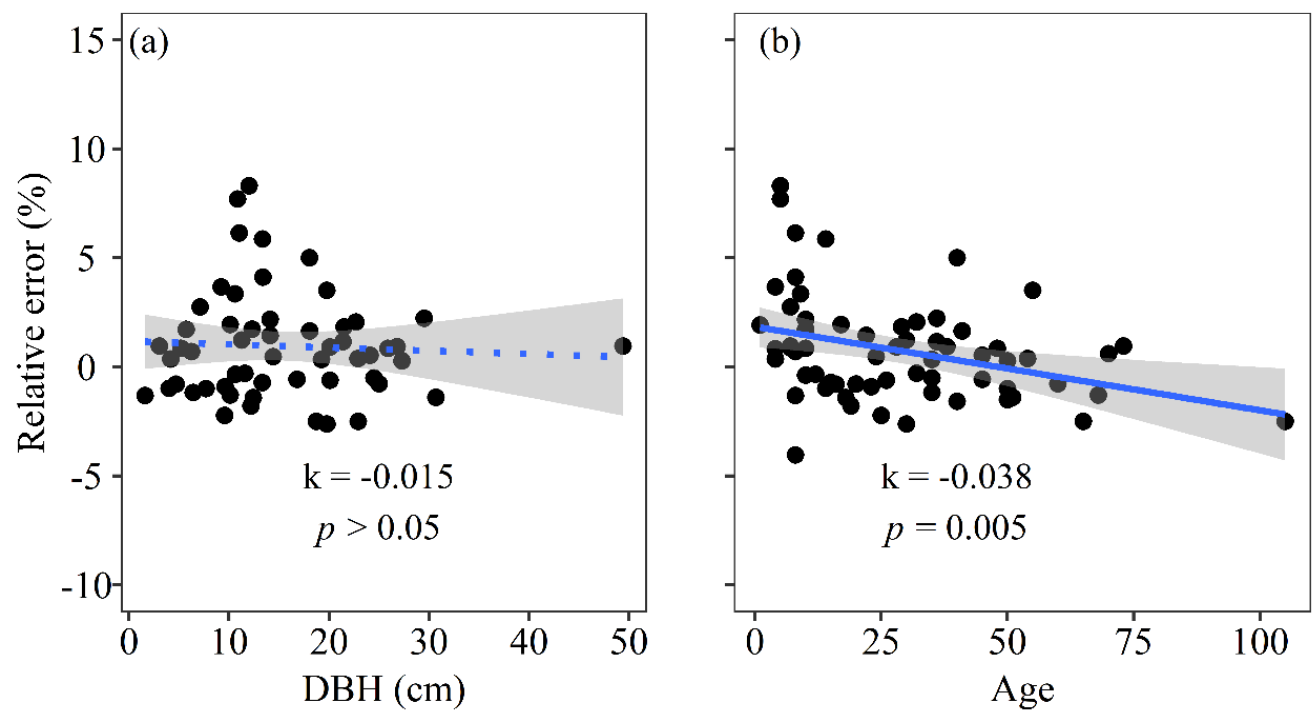